\title{
El café, \\ estimulante social y cultural
}

\author{
José Rubén Castillo García \\ Docente Fisioterapia
}

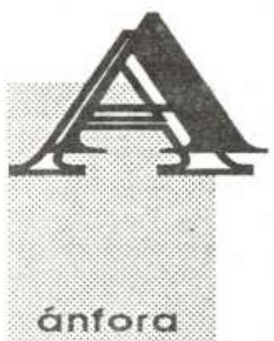

firmar que el café es un estimulante, en una sociedad como la nuestra que ha sufrido el permanente señalamiento por parte de diversos sectores, convierte a quien lo haga en un «pecador" por contribuir a que se siga acusando y quizás condenando a nuestra maltrecha sociedad Colombiana, dado que la economía «santa» del país tiene mucho que ver con la producción, recolección, distribución y consumo del café.

Sin embargo, es una necesidad urgente el afirmar y reconfirmar que dicha sustancia ha sido, es y será por un buen tiempo, uno de nuestros mejores estimulantes. Vale la pena aclarar que en nuestra opinión el sentido con el cual se maneja el término «estimulante», debe trascender el concepto peyorativo, despectivo, biologista y pecaminoso con el cual se juzgan los denominados estimulantes. En este caso, no se busca hacer referencia a las consecuencias biológicas y funcionales relacionadas con el consumo del café; se trata de mirar otros aspectos en los cuales ha incidido esta sustancia en nuestro medio.

Se parte del hecho de que las condiciones de vida y las diferentes expresiones culturales de nuestra población, sobre todo de la región del Viejo Caldas, tienen que ver con los acontecimientos económicos y sociales derivados de los diferentes procesos relacionados con el café, a tal punto que

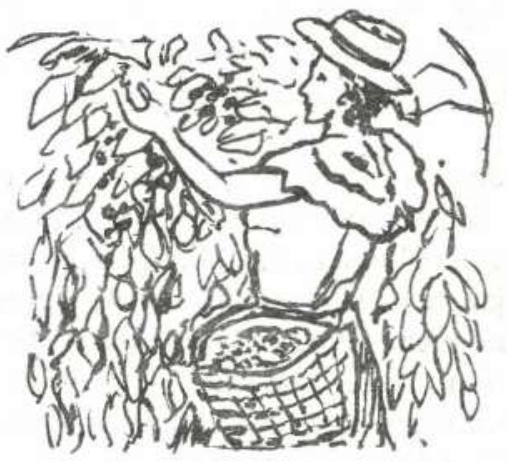

cerca de 300.000 familias en el país y 34.000 en el departamento de Caldas en términos generales, viven del café («La Patria», feb. 20/91).

Desde los inicios de la siembra y cultivo del café, se dieron situaciones especiales que han incidido en el funcionamiento de la sociedad Colombiana. Veamos.

El origen del cultivo del café, por su carácter de no ser artículo de primera necesidad, tiene que ver más con las posibilidades de comercialización que con la búsqueda de autosostenimiento de la familia. Por lo tanto, aunque las actividades cafeteras se dan en el campo, su sentido es el de buscar consolidarlo como un producto susceptible de ser comercializado, de obtener ganancias y quizás riquezas con base en él. 
Esta perspectiva condujo al desarrollo de economías locales basadas en las pequeñas propiedades, donde se entraron a privilegiar la lucha de los hombres por controlar la naturaleza, el espíritu emprendedor, el trabajo fecundo y creador de las familias. Esto, en parte, explica el fomento de estructuras familiares extensas entre la población campesina adscrita a este tipo de economía.

La necesidad de comercializar el producto incentivó la manera de adecuar y de construir un sistema de vías que permitiera comercializarlo, favoreciendo de esta manera el desarrollo de regiones a nivel de la infraestructura.

Los ingresos provenientes de la venta de café, fortalecieron la capacidad de compra y de consumo por parte de los productores, además del fomento de inversiones, sobre todo a nivel urbano. De ahí que la ilusión de los campesinos era la de tener una propiedad en la ciudad, al contrario de lo que acontece en la actualidad con la población urbana. No sobra decir que estos procesos de intercambio de negociación y de inversiones dependen obviamente de los períodos de cosecha. Por esto, se puede decir que los cultivadores de este producto han desarrollado pautas de consumo de extremos, puesto que sus gastos son reflejo de la situación que viven en el momento, dado que oscilan entre la bonanza y los períodos de austeridad, según sea el caso.

La valorización de las propiedades, el auge de las exportaciones y la acumulación de capitales, permitieron la formación de sectores sociales cuya fortaleza económica les dieron la posibilidad de invertir en la producción industrial, siendo este un renglón de la economía seriamente afectado por el capital proveniente del café.

El consumo de este producto, ha generado también importantes pautas culturales que tienen que ver con el modo de vida, con la manera de captar y de transformar la realidad. Esto afecta tanto la vida particular de los individuos, del hogar, de las familias y la vida social que se lleva a cabo en los espacios públicos.

Veamos qué ocurre en cada uno de ellos.

La vida de familia, la ha determinado en gran parte los acontecimientos que se presentan alrededor de la "cocina», puesto que este es el lugar en el cual se llevan a cabo los diálogos a nivel de sus miembros. Allí se llevan a cabo las sesiones de cuentos, las narraciones de acontecimientos sobrenaturales, incluidas las exageraciones y las mentiras. También se aprovechan estas tertulias para llevar a cabo los procesos de socialización, la educación en los valores $\mathrm{y}$ en las tradiciones. No sobra decir que esto se realiza en torno de suculentas tasas de tinto, amenizadas en muchos casos con el ritmo de la música de cuerda.

El hogar, es el espacio en el cual se comparten experiencias, se plantean las ilusiones para el futuro y se construye la identidad cultural. Las casas son decoradas con emblemas religiosos, imágenes de santos, bustos, crucifijos. Las comidas tienen el predominio de los carbohidratos con base en los cuales se pretende recuperar las energías perdidas durante la jornada laboral; entre ellos se destacan el agua de panela, las arepas, los fríjoles, el sancocho, el arroz, el chocolate, la mazamorra y obviamente el tinto hecho con base en la panela.

La vida pública se enmarca dentro de viviendas elaboradas básicamente con guadua, con corredores bordeados con barandas de chambranas pintadas con colores intensos y brillantes y con paredes bahareque. Este conjunto de construcciones están ubicadas alrededor de una plaza central de forma rectangular, en uno de cuyos lados generalmente existe una iglesia. 
La vida social de las familias está regida en buena parte por acontecimientos de origen religioso de dos tipos. A nivel particular de cada familia se celebra el bautizo, la primera comunión, el matrimonio y se acostumbra acompañar los deudos en los velorios en los cuales se sirve permanentemente el tinto, mientras se recuerdan las buenas obras del difunto y/o se escuchan cuentos de todos los colores. A nivel general son acontecimientos importantes la semana santa, la cual se aprovecha para estrenar ropa; al igual que durante las celebraciones de navidad para reunir el conjunto de parientes.

Los lugares de encuentro de los campesinos en las zonas rurales fueron las denominadas «fondas», espacios en los cuales además de tazas de café se hacían los negocios, se consumía licor, se llevaban a cabo las denominadas tertulias, donde se hablaba de política, de economía, de historias y demás temas de contenido social y de interes colectivo. En las ciudades, con el mismo sentido, se establecieron los denominados "cafés», luga- res donde además de consumir el preciado líquido se realizaban encuentros entre amigos, se realizaban negocios, los estudiantes departían, construían «el futuro del país» y más de un intelectual pretendía dictar cátedra sobre los acontecimientos del momento.

Hoy en día, muchas de las situaciones presentadas anteriormente han venido siendo reemplazadas por la «modernidad», pero estoy convencido de que han sido muchas las cosas importantes que se han definido en torno de cualquiera de las partes del proceso que tiene que ver con el café. Por esto, insisto en que "el café es un estimulante», más que biológico (porque ese no fue nuestro tema), social y cultural, por la manera como ha incentivado e influenciado la vida de los pobladores de nuestra región. No sobra decir que al inicio de este tema y durante la captación, organización, construcción, elaboración y presentación de estas ideas estuvieron presentes sendas tazas de tinto que sirvieron para amenizar este esfuerzo por compartir con los lectores nuestras opiniones.

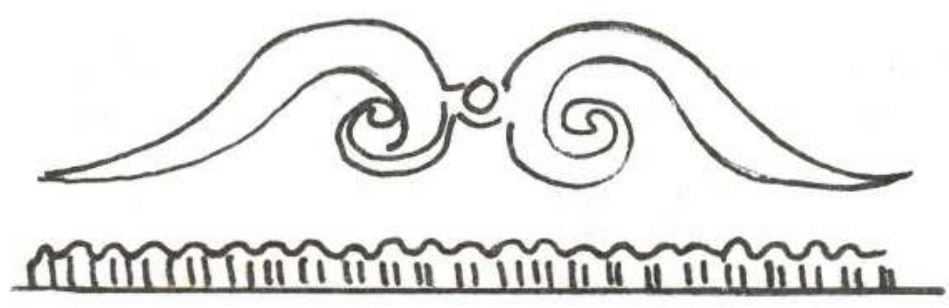

